\title{
New cycles of innovation in a mature industry: the camera industry 1955-1974
}

Citation for published version (APA):

Windrum, P. (2003). New cycles of innovation in a mature industry: the camera industry 1955-1974. MERIT, Maastricht Economic Research Institute on Innovation and Technology. MERIT-Infonomics Research Memorandum Series No. 024 https://doi.org/10.26481/umamer.2003024

Document status and date:

Published: 01/01/2003

DOI:

10.26481/umamer.2003024

Document Version:

Publisher's PDF, also known as Version of record

\section{Please check the document version of this publication:}

- A submitted manuscript is the version of the article upon submission and before peer-review. There can be important differences between the submitted version and the official published version of record.

People interested in the research are advised to contact the author for the final version of the publication, or visit the DOI to the publisher's website.

- The final author version and the galley proof are versions of the publication after peer review.

- The final published version features the final layout of the paper including the volume, issue and page numbers.

Link to publication

\footnotetext{
General rights rights.

- You may freely distribute the URL identifying the publication in the public portal. please follow below link for the End User Agreement:

www.umlib.nl/taverne-license

Take down policy

If you believe that this document breaches copyright please contact us at:

repository@maastrichtuniversity.nl

providing details and we will investigate your claim.
}

Copyright and moral rights for the publications made accessible in the public portal are retained by the authors and/or other copyright owners and it is a condition of accessing publications that users recognise and abide by the legal requirements associated with these

- Users may download and print one copy of any publication from the public portal for the purpose of private study or research.

- You may not further distribute the material or use it for any profit-making activity or commercial gain

If the publication is distributed under the terms of Article $25 \mathrm{fa}$ of the Dutch Copyright Act, indicated by the "Taverne" license above, 


\section{MERIT-Infonomics Research Memorandum series}

New cycles of innovation in a mature industry: the camera industry 1955-1974

\section{Paul Windrum}

2003-024

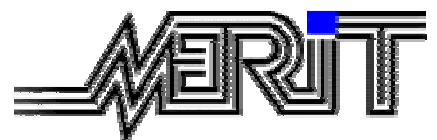

MERIT - Maastricht Economic Research Institute on Innovation and Technology

PO Box 616

6200 MD Maastricht

The Netherlands

$\mathrm{T}:+31433883875$

$F:+31433884905$

http://www.merit.unimaas.nl e-mail:secr-merit@merit.unimaas.nl



International Institute of Infonomics

c/o Maastricht University PO Box 616 6200 MD Maastricht The Netherlands T: +31433883875 F: +31453884905

http://www.infonomics.nl e-mail: secr@infonomics.nl 